\title{
Hydrothermal synthesis and characterization of straw bundle-like lithium sodium disilicate (silinaite) micro-rods
}

\author{
Abdolali Alemi ${ }^{1}$, Sang Woo Joo ${ }^{2}$, Shahin Khademinia ${ }^{*}$, Mahboubeh Dolatyari $^{3}$, Akbar Bakhtiari $^{4}$, \\ Hossein Moradi ${ }^{5}$ and Sorayya Saeidi ${ }^{6}$
}

\begin{abstract}
Highly mono-shaped straw bundle-like silinaite micro-rods have been synthesized using an aqueous mixture of silicic acid, lithium sulfate, and sodium hydroxide under hydrothermal conditions at $180^{\circ} \mathrm{C}$. The synthesized materials were characterized by powder X-ray diffraction technique and Fourier transform infrared spectroscopy. The morphologies of the synthesized materials were studied by field emission scanning electron microscopy technique. The synthesized micro-rods are composed of long, fine nanosheets. Electronic absorption and photoluminescence spectra of the synthesized materials were also studied. With increasing reaction time, a blueshift was observed in the UV-vis electronic absorption and emission spectra of the synthesized materials.
\end{abstract}

Keywords: Hydrothermal method, Lithium sodium silicate, Optical properties, Micro-rods

\section{Background}

Layered compounds are of scientific and technological interest. They act not only as exchanger and fillers in detergents and nanocomposites [1,2] but also as hosts for intercalation of functional molecules or ions to yield hybrid materials [3]. Silinaite (lithium sodium silicate, $\mathrm{LiNaSi}_{2} \mathrm{O}_{5} \cdot 2 \mathrm{H}_{2} \mathrm{O}$ ) is a monophyllosilicate consisting of layers of $\left[\mathrm{SiO}_{4}\right]$ tetrahedra parallel to (001). The lithium ions are held in tetrahedral coordination by four oxygen ions from four $\left[\mathrm{SiO}_{4}\right]$ tetrahedra and pull the layers together. The octahedra around the sodium ions consist of four oxygen atoms from water molecules and two oxygen ions which also belong to $\left[\mathrm{SiO}_{4}\right]$ and $\left[\mathrm{LiO}_{4}\right]$ tetrahedra. The $\left[\mathrm{NaO}_{6}\right]$ octahedra bulge the layers somewhat apart so that the layers are slightly undulated [4].

Natural silinaite was identified and separated from minerals in $1990[5,6]$. Also, the crystal structure of silinaite was determined in 1991 [7]. Bulk silinaite was synthesized by dispersion of silica in aqueous solutions

\footnotetext{
* Correspondence: shahinkhademinia@gmail.com

'Department of Inorganic Chemistry, Faculty of Chemistry, University of Tabriz, Tabriz, Iran

Full list of author information is available at the end of the article
}

of $\mathrm{NaOH}$ and $\mathrm{LiOH}$ at $90^{\circ} \mathrm{C}$ to $150^{\circ} \mathrm{C}$ [4]. Also, the compound is synthesized by hydrothermal crystallization of the gel formed by an aqueous mixture of water glass, $\mathrm{NaOH}$, and $\mathrm{LiOH}$ [8]. Among the low-temperature methods, the hydrothermal method is very versatile for the synthesis of nanophase materials and has been well established. This is an environment friendly method because the reactions take place in closed-system conditions and save energy [9-11]. In this research work, we report a simple hydrothermal approach to the synthesis of new multi-layer straw bundle-like silinaite micro-rods with a regular new morphology. The morphology and optical properties of the obtained materials are investigated. Also, cell parameter refinement performed by Celref software version 3 (Laboratoire des Materiaux et du Génie Physique de l'Ecole Supérieure de Physique de Grenoble, Grenoble, France) shows the preferential orientation of crystals in the products due to changing the reaction time.

\section{Methods}

All chemicals were of analytical grade, obtained from commercial sources, and used without further purification. Phase identifications were performed on a Siemens D5000 powder X-ray diffractometer (Siemens, 

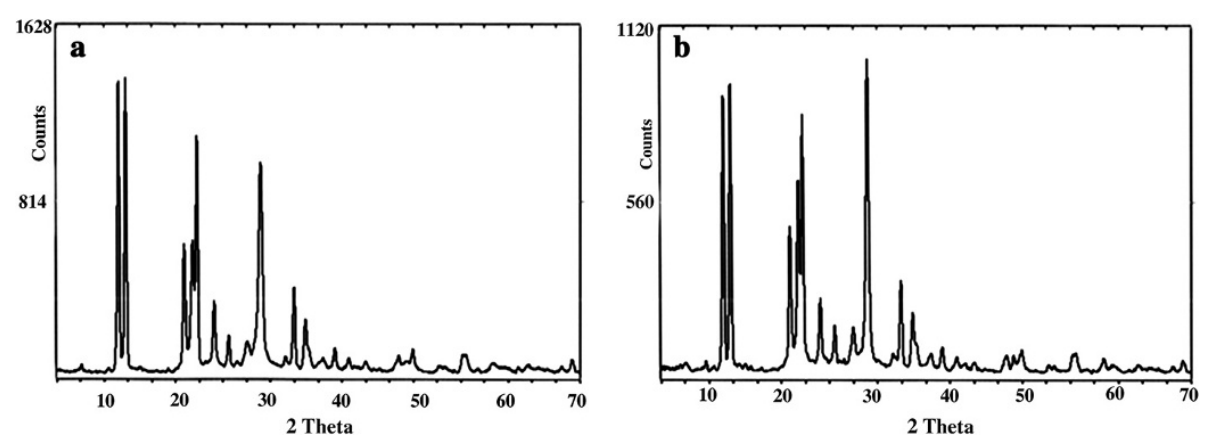

Figure 1 PXRD patterns of the $\mathrm{LiNaSi}_{2} \mathrm{O}_{5} \cdot \mathbf{2} \mathrm{H}_{2} \mathrm{O}$ micro-rods hydrothermally synthesized at $180^{\circ} \mathrm{C}$. After (a) 48 and (b) $72 \mathrm{~h}$.

Munich, Germany) using $\mathrm{CuK}_{\alpha}$ radiation. The morphology of the obtained materials was examined with a Philips XL30 scanning electron microscope (Philips, Amsterdam, Netherlands). Absorption and photoluminescence spectra were recorded on a Jena Analytik Specord 40 (Jena, Germany) and a Perkin Elmer LF-5 (Waltham, MA, USA) spectrometer, respectively. Cell parameter refinement was performed by Celref version 3 software.

\section{Synthesis of lithium sodium disilicate (silinaite)}

In a typical synthetic experiment, $0.3 \mathrm{~g}(2.3 \mathrm{mmol})$ of $\mathrm{Li}_{2} \mathrm{SO}_{4} \cdot \mathrm{H}_{2} \mathrm{O}\left(M_{\mathrm{w}}=127.95 \mathrm{gmol}^{-1}\right)$ and $0.44 \mathrm{~g}(4.6 \mathrm{mmol})$

Table 1 Crystallographic data of the hydrothermally synthesized $\mathrm{LiNaSi}_{2} \mathrm{O}_{5} .2 \mathrm{H}_{2} \mathrm{O}$ nanomaterials obtained after $48 \mathrm{~h}$ at $180^{\circ} \mathrm{C}$

\begin{tabular}{|c|c|c|c|}
\hline Number & $2 \theta$ & Intensity & Inter-planar space \\
\hline 1 & 11.86 & 1,282 & 7.456 \\
\hline 2 & 12.77 & 1,300 & 6.928 \\
\hline 3 & 20.13 & 506 & 4.408 \\
\hline 4 & 21.19 & 303 & 4.189 \\
\hline 5 & 21.73 & 803 & 4.087 \\
\hline 6 & 23.90 & 284 & 3.719 \\
\hline 7 & 25.75 & 142 & 3.457 \\
\hline 8 & 28.13 & 75 & 3.169 \\
\hline 9 & 29.77 & 901 & 2.999 \\
\hline 10 & 32.93 & 39 & 2.717 \\
\hline 11 & 33.98 & 360 & 2.636 \\
\hline 12 & 35.42 & 166 & 2.532 \\
\hline 13 & 39.13 & 94 & 2.300 \\
\hline 14 & 40.90 & 45 & 2.204 \\
\hline 15 & 43.02 & 36 & 2.101 \\
\hline 16 & 47.21 & 41 & 1.924 \\
\hline 17 & 48.97 & 71 & 1.859 \\
\hline 18 & 69.12 & 50 & 1.358 \\
\hline
\end{tabular}

of $\mathrm{SiO}_{2} \cdot \mathrm{H}_{2} \mathrm{O}\left(M_{\mathrm{w}}=96.11 \mathrm{gmol}^{-1}\right)$ were added to $30 \mathrm{~mL}$ of hot aqueous solution of $\mathrm{NaOH}(0.23 \mathrm{M})$ under magnetic stirring at $80^{\circ} \mathrm{C}$. The resultant solution was stirred further for $15 \mathrm{~min}$ and then diluted to $60 \mathrm{~mL}$. The resultant solution was transferred into a 100-mL Teflonlined stainless steel autoclave. The autoclave was sealed and heated at $180^{\circ} \mathrm{C}$ for $48 \mathrm{~h}$ (sample a) or $72 \mathrm{~h}$ (sample b) and then cooled to room temperature by water immediately. When the reaction was completed, a white powder was collected from the solution and washed with distilled water. The prepared powder was dried at $110^{\circ} \mathrm{C}$ for 20 min under normal atmospheric conditions.

Table 2 Crystallographic data of the hydrothermally synthesized $\mathrm{LiNaSi}_{2} \mathrm{O}_{5} \cdot 2 \mathrm{H}_{2} \mathrm{O}$ nanomaterials obtained after $72 \mathrm{~h}$ at $180^{\circ} \mathrm{C}$

\begin{tabular}{lccc}
\hline Number & $\mathbf{2 \theta}$ & Intensity & Inter-planar space \\
\hline 1 & 11.83 & 837 & 7.471 \\
2 & 12.72 & 877 & 6.956 \\
3 & 20.10 & 401 & 4.414 \\
4 & 21.16 & 359 & 4.195 \\
5 & 21.68 & 572 & 4.096 \\
6 & 23.89 & 194 & 3.722 \\
7 & 25.68 & 114 & 3.466 \\
8 & 27.99 & 96 & 3.185 \\
9 & 29.76 & 942 & 3.000 \\
10 & 33.92 & 259 & 2.641 \\
11 & 35.41 & 124 & 2.533 \\
12 & 37.59 & 37 & 2.391 \\
13 & 39.05 & 67 & 2.304 \\
14 & 47.05 & 37 & 1.930 \\
15 & 47.99 & 29 & 1.894 \\
16 & 48.91 & 44 & 1.861 \\
17 & 59.22 & 34 & 1.559 \\
18 & 69.06 & 52 & 1.358 \\
\hline & & &
\end{tabular}


Table 3 Refined cell parameter data of the $\mathrm{LiNaSi}_{2} \mathrm{O}_{5} \cdot 2 \mathrm{H}_{2} \mathrm{O}$ nanomaterials hydrothermally synthesized at $180^{\circ} \mathrm{C}$

\begin{tabular}{lcc}
\hline $\begin{array}{l}\text { Refined } \\
\text { cell } \\
\text { parameters }\end{array}$ & \multicolumn{2}{c}{ Reaction times } \\
\cline { 2 - 3 } & $\mathbf{4 8 \mathbf { h }}$ & $\mathbf{7 2 ~ \mathbf { ~ }}$ \\
\hline$a$ & 5.021 & 5.077 \\
$b$ & 8.2895 & 8.3118 \\
$c$ & 14.5418 & 14.4189 \\
\hline
\end{tabular}

\section{Results and discussion PXRD analysis}

The crystal phase and chemical composition of the synthesized samples were examined by powder X-ray diffraction (PXRD) technique. The PXRD patterns of the synthesized $\mathrm{LiNaSi}_{2} \mathrm{O}_{5} \cdot 2 \mathrm{H}_{2} \mathrm{O}$ samples, obtained after 48 and $72 \mathrm{~h}$, are shown in Figure 1. All diffraction peaks in the PXRD patterns of the as-prepared $\mathrm{LiNaSi}_{2} \mathrm{O}_{5} \cdot 2 \mathrm{H}_{2} \mathrm{O}$ materials can be clearly indexed to the monoclinic phase of the natural silinaite with space group A2/n. There are four molecules per unit cell, $Z=4$ [7], which is identified by a group of the reflections around $2 \theta=21.3^{\circ}$ in the X-ray diffraction diagram $[4,6-8,12]$. The corresponding cell parameters are $a=5.06 \AA, b=8.33 \AA, c=14.38 \AA$, and $\beta=96.67^{\circ}$ [13]. The measured PXRD data show no impurity peaks, indicating the high purity of the as-obtained samples. Because of the different coordination modes of $\mathrm{Na}^{+}$ (octahedral) and $\mathrm{Li}^{+}$(tetrahedral) ions in the structure,

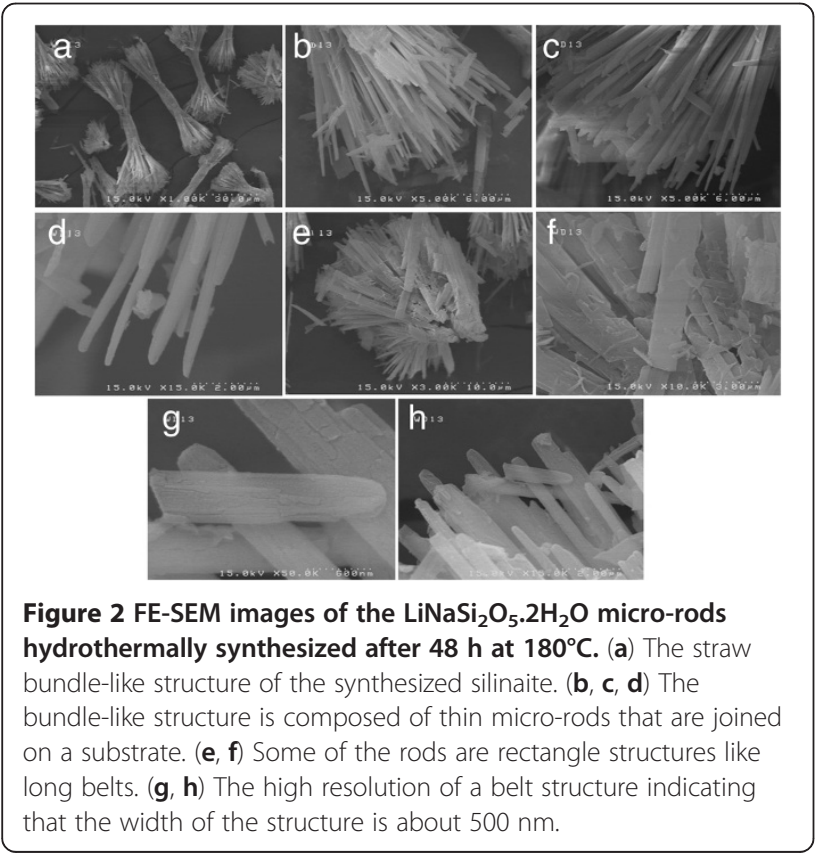

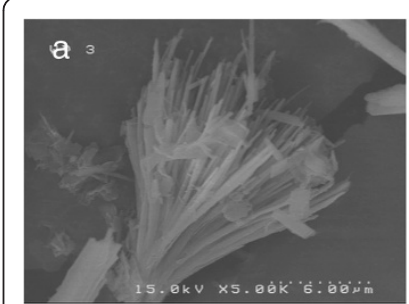
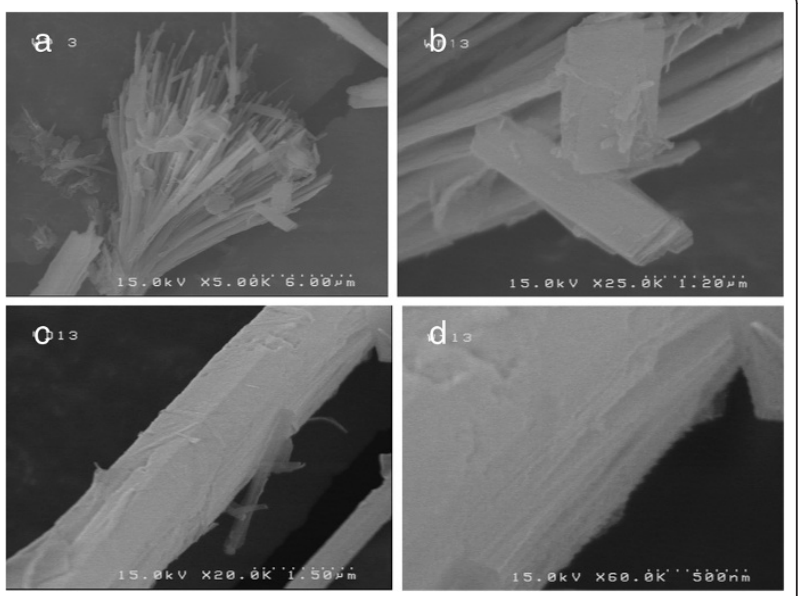

Figure $3 \mathrm{FE}-\mathrm{SEM}$ images of the $\mathrm{LiNaSi}_{2} \mathrm{O}_{5} .2 \mathrm{H}_{2} \mathrm{O}$ micro-rods hydrothermally synthesized after $72 \mathrm{~h}$ at $180^{\circ} \mathrm{C}$. $(\mathrm{a}, \mathrm{b})$ The straw bundle-like structure of the synthesized silinaite composed of thin micro-rods, some of which are belt-like structures. (c, d) The trunks themselves are composed of sheets that are compacted tightly.

substitution of sodium ions by lithium ions cannot occur without structural rearrangements [4]. Also, inter-planar spacing in the crystalline material is calculated via Bragg's law $\left(n \lambda=2 d_{\mathrm{hkl}} \sin \theta\right)$ with the strongest peak in $48 \mathrm{~h}$ (12.77 with peak intensity of 1,300$)$ selected as reference to calculate the parameter $d$. Thus, $\left(\Delta 2 \theta=12.77(48 \mathrm{~h})-12.72(72 \mathrm{~h})=0.05^{\circ}\right)$, $(\Delta d=6.956(72 \mathrm{~h})-6.928(48 \mathrm{~h})=0.028 \AA)$. The data show that there is a shift to lower $2 \theta$ value, and so with increasing the reaction time, there is an expansion in unit cell. To calculate the crystal sizes, we used XRD pattern peaks at $2 \theta=12.77^{\circ}$ for the 48 -h reaction time and $2 \theta=12.72^{\circ}$ for the $72-\mathrm{h}$ reaction time. Crystal sizes that were measured via the Debye-Scherrer equation are as follows: $35.88 \mathrm{~nm}(48 \mathrm{~h})$ and $35.91 \mathrm{~nm}(72 \mathrm{~h})$. In addition, the intense and sharp diffraction peaks suggest that the as-synthesized products are well crystallized. In

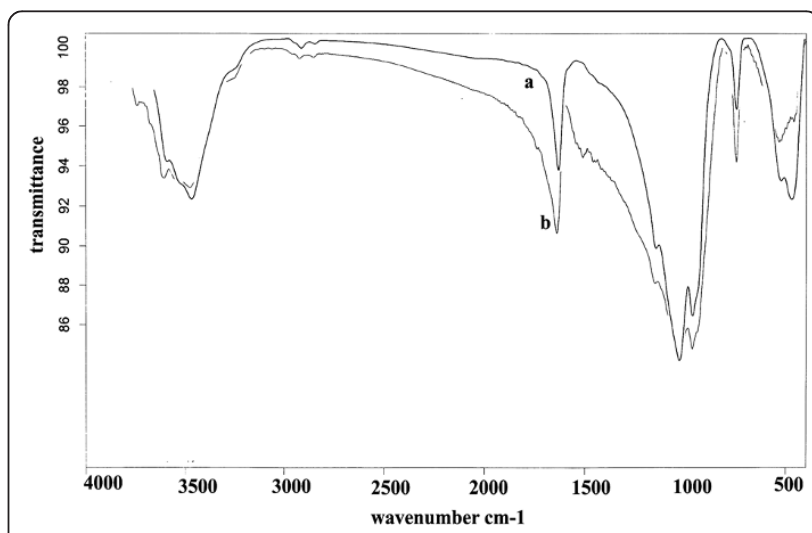

Figure 4 FT-IR spectra of the $\mathrm{LiNaSi}_{2} \mathrm{O}_{5} \cdot 2 \mathrm{H}_{2} \mathrm{O}$ micro-rods hydrothermally synthesized at $180^{\circ} \mathrm{C}$. After (a) 48 and (b) $72 \mathrm{~h}$. 


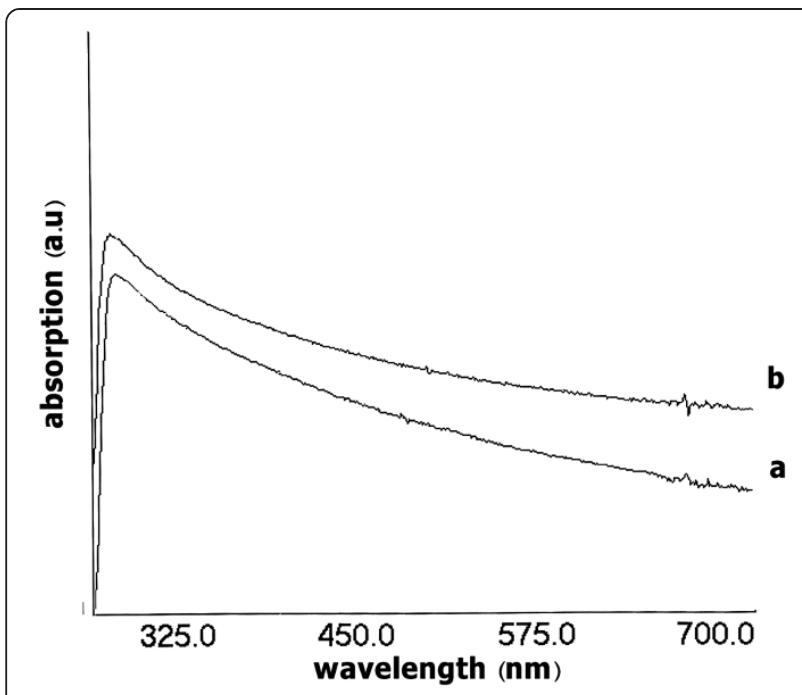

Figure 5 UV-visible absorption spectra of the $\mathrm{LiNaSi}_{2} \mathrm{O}_{5} \cdot 2 \mathrm{H}_{2} \mathrm{O}$ micro-rods hydrothermally synthesized at $180^{\circ} \mathrm{C}$. After (a) 48 and (b) $72 \mathrm{~h}$

the PXRD pattern of sample b, compared to that of sample a, all peak intensities has decreased. However, in pattern $b$ compared to that of $a$, the peak at $2 \theta \approx$ $12.5^{\circ}$ shows a considerable decreased intensity, and the intensity of the peak at $2 \theta \approx 30^{\circ}$ is significantly enhanced, indicating the preferred crystallographic orientation of the crystals in the products. Tables 1 and 2 show the $2 \theta$ values with their intensities and inter-planar spaces. Tables 1 and 2 show that with increasing reaction time, some peak intensities were decreased until hidden in the background. Table 3 shows the refined cell parameters calculated by Celref software version 3. As shown in Table 3 , it is clear that with increasing reaction time, parameters $a$ and $b$ corresponding to reference [7] as the interlamellar and intralamellar parameters in the direction of [100] and [010] increased from 5.021 to $5.077 \AA$ and 8.289 to $8.3118 \AA$, respectively. Thus, we can conclude that the unit cell has expanded in the direction of [100] and [010]. However, parameter $c$ that corresponds to the direction of [001] decreased from 14.542 to $14.419 \AA$, so in this direction, there is a contraction. Also, the volume of the unit cell was calculated by Celref software version 3 from $0.60273 \mathrm{~nm}^{3}$ that increased to $0.61014 \mathrm{~nm}^{3}$. Thus, we can conclude that there is an expansion in the unit cell.

\section{Microstructure analysis}

Figures 2 and 3 show the field emission scanning electron microscopy (FE-SEM) images of the $\mathrm{LiNaSi}_{2} \mathrm{O}_{5} \cdot 2 \mathrm{H}_{2} \mathrm{O}$ micro-rods hydrothermally synthesized, respectively, after 48 and $72 \mathrm{~h}$ at $180^{\circ} \mathrm{C}$. The synthesized samples are composed of highly monodispersed straw bundle-like silinaite micro-rods with a length and width of about 10 to $15 \mu \mathrm{m}$ and $400 \mathrm{~nm}$, respectively (Figure 2). Figure 2a shows the straw bundle-like structure of the synthesized silinaite. Figure $2 \mathrm{~b}, \mathrm{c}, \mathrm{d}$ shows that the bundle-like structure is composed of thin micro-rods that are joined on a substrate. Figure 2e,f shows that some of the rods are rectangle structures like long belts. Figure $2 \mathrm{~g}$,h shows the high resolution of a belt structure, indicating that the width of the structure is about $500 \mathrm{~nm}$. Also, the vertical-section view of an individual straw bundle-like $\mathrm{LiNaSi}_{2} \mathrm{O}_{5} \cdot 2 \mathrm{H}_{2} \mathrm{O}$ (Figure 2d) reveals that the thickness of the rods is about $100 \mathrm{~nm}$. High-magnification images of the as-synthesized material (see Figure 3) show that trunks split into long, fine nanosheets. Figure $3 \mathrm{a}, \mathrm{b}$ shows that the straw bundle-like structure of the synthesized silinaite is composed of thin micro-rods some of which are belt-like structures. Figure 3c,d shows seemingly that the trunks themselves are composed of sheets that are compacted tightly.

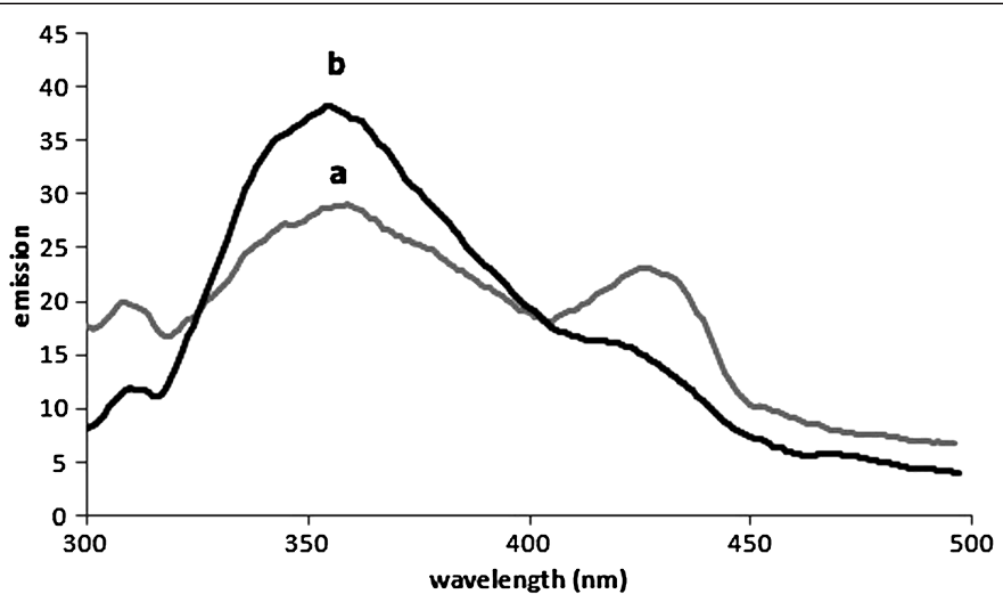

Figure 6 Emission spectra of the $\mathrm{LiNaSi}_{2} \mathrm{O}_{5} \cdot \mathbf{2} \mathrm{H}_{2} \mathrm{O}$ micro-rods hydrothermally synthesized at $\mathbf{1 8 0}^{\circ} \mathrm{C}$. After (a) 48 and (b) $72 \mathrm{~h}$ $(\lambda$ excitation $=220 \mathrm{~nm})$. 


\section{Optical properties}

Figure 4 shows the Fourier transform infrared (FT-IR) spectra of the synthesized $\mathrm{LiNaSi}_{2} \mathrm{O}_{5} \cdot 2 \mathrm{H}_{2} \mathrm{O}$ micro-rods. The broad absorption bands at 3,480 and $3,270 \mathrm{~cm}^{-1}$ are assigned as stretching vibrations of interlamellar water molecules $[4,8]$. The band at $456 \mathrm{~cm}^{-1}$ is characteristic of $\mathrm{Li}-\mathrm{O}$ stretching vibration. The bands observed at 1,038 and $965 \mathrm{~cm}^{-1}$ are assigned to the Si-O-Si asymmetric stretching vibration. Also, the symmetric stretching vibration mode of $\mathrm{Si}-\mathrm{O}-\mathrm{Si}$ is observed at $749 \mathrm{~cm}^{-1}$. Moreover, the bending vibration mode of $\mathrm{O}-\mathrm{Si}-\mathrm{O}$ is observed at 534 and $467 \mathrm{~cm}^{-1}[4,8]$.

Figure 5 shows the UV-vis absorption spectra of the synthesized straw bundle-like $\mathrm{LiNaSi}_{2} \mathrm{O}_{5} \cdot 2 \mathrm{H}_{2} \mathrm{O}$ microrods, measured at room temperature. A sharp absorption band at 276 and $272 \mathrm{~nm}$ is observed respectively for samples a and $\mathrm{b}$. According to the absorption electronic spectra, the bandgap of the synthesized $\mathrm{LiNaSi}_{2} \mathrm{O}_{5} \cdot 2 \mathrm{H}_{2} \mathrm{O}$ micro-rods is calculated to be $4.49 \mathrm{eV}$ (for sample a) and $4.56 \mathrm{eV}$ (for sample b).

Figure 6 represents the room-temperature emission spectra of the as-synthesized materials under excitation at 220 $\mathrm{nm}$. A strong broad emission band at 358 and $355 \mathrm{~nm}$ is observed for samples a and b, respectively.

\section{Conclusions}

In summary, uniform straw bundle-like silinaite microrods were successfully synthesized by a simple hydrothermal method. The synthesized micro-rods are composed of long, fine nanosheets. We found that the reaction time has no effect on the morphology of the products. However, the preferred crystallographic orientation of the crystals in the products changes with reaction time. UV-vis electronic absorption and emission spectra of the synthesized materials were investigated. Also, cell parameter refinement was calculated by Celref software version 3 .

\section{Competing interests}

The authors declare that they have no competing interests.

\section{Authors' contributions}

$A A, S K, S W J, M D, A B, H M$, and SS participated in the experiments. All authors read and approved the final manuscript.

\footnotetext{
Authors' information

SK got his B.S. degree from the University of Birjand in the field of applied chemistry in 2007. He got his M.Sc. degree from the University of Tabriz in the field of inorganic chemistry in August 2010. He is now a Ph.D. student at the Faculty of Chemistry, University of Semnan, Iran, in the field of inorganic chemistry. AA got his B.S. and M.Sc. degree from the University of Tabriz, Iran, in the fields of chemistry in 1972 and 1974, respectively. He got his Ph. D. degree from the University of Paris, France, in the field of inorganic chemistry in 1978. He is now a professor in inorganic chemistry at the University of Tabriz, Iran. MD got his B.S. and M.Sc. degree from the University of Tabriz, Iran, in the fields of chemistry and inorganic chemistry in 2004 and 2006, respectively. He got his Ph.D. degree from the University of Tabriz, Iran, in the field of inorganic solid-state chemistry in 2010. She is now a postdoctorate student in the research group of Prof. Rostami at the School
}

of Engineering Emerging Technologies, University of Tabriz, Iran, and an associate professor in the Department of Inorganic Chemistry, University of Tabriz, Iran. AB got his B.S. and M.Sc. degree from the University of Tabriz, Iran, and from the University of Urmia in the fields of chemistry and inorganic chemistry in 2004 and 2006, respectively. He got his Ph.D. degree from the University of Tabriz, Iran, in the field of inorganic chemistry in 2010. He is now an associate professor at the University of Payamenoor, Tehran HM is now an M.SC. student of Azad University, branch of Ardabil, in the field of inorganic chemistry. SS is now a Ph.D. student at the Faculty of Science of Nature, University of Tabriz.

\section{Acknowledgements}

The authors express their sincere thanks to the authorities of Tabriz University for financing the project.

\section{Author details}

'Department of Inorganic Chemistry, Faculty of Chemistry, University of Tabriz, Tabriz, Iran. ${ }^{2}$ School of Mechanical Engineering WCU Nano Research Center, Yeungnam University, Gyeongsan 712-749, South Korea. ${ }^{3}$ Laboratory of Photonics and Nano Crystals, School of Engineering-Emerging Technologies, University of Tabriz, Tabriz, Iran. ${ }^{4}$ Department of Chemistry, Payame Noor University, Tehran 19395-4697, Iran. ${ }^{5}$ Faculty of Chemistry, Islamic Azad University, Ardabil Branch, Ardabil, Iran. ${ }^{6}$ Faculty of Science of Nature, Department of Geology, University of Tabriz, Tabriz, Iran.

Received: 16 June 2012 Accepted: 9 May 2013

Published: 24 May 2013

\section{References}

1. Murray, HH: Traditional and new applications for kaolin, smectite, and palygorskite: a general overview. Appl. Clay. Sci. 17, 207 (2000)

2. Zhou, CH, Ge, ZH, Li, XN, Guo, HQ: Mesoporous silicoaluminum pillared clays with high thermal stability and Brønsted/Lewis acidity by one-pot synthesis. J. Chin. Chem. Lett. 14, 1285 (2003)

3. Peter, C, Baron, L, Wang, Z, Pinnavaia, T: Polymer-layered silicate nanocomposites: an overview. J. Appl. Clay. Sci. 15, 11 (1999)

4. Beneke, K, Thiesen, P, Lagaly, G: Synthesis and properties of the sodium lithium silicate silinaite. Inorg. Chem. 34, 900 (1995)

5. Chao, GY, Conlon, RP: $(\mathrm{Na}, \mathrm{K})_{2}(\mathrm{Mn}, \mathrm{Fe}, \mathrm{Ca}, \mathrm{Ti}, \mathrm{Al})_{3}(\mathrm{Si}, \mathrm{Al}) 8 \mathrm{O}_{20} \cdot 8 \mathrm{H}_{2} \mathrm{O}$; Mont St. Hilaire "UK38"; later equatzakharovite by original authors: Velthuizen J. V. Mineral Record 21, 363 (1990)

6. Chao, GY, Grice, JD, Gault, RA: Silinaite, a new sodium lithium silicate hydrate mineral from Mont Saint-Hilaire. Quebec. Can. Mineral. 29, 359 (1991)

7. Grice, JD: The crystal structure of silinaite, $\mathrm{NaLiSi}_{2} \mathrm{O}_{5} \cdot 2 \mathrm{H}_{2} \mathrm{O}$ : a monophyllosilicate. Can. Mineral 29, 363 (1991)

8. Zhou, CH, Guo, HQ Cao, HJ, Li, XN, Ge, ZH: Li: Synthesis and characterization of novel layered lithium sodium silicate (Silinaite) and the mesoporous materials from silinaite. J. Chinese Chem. Lett. 17, 525 (2006)

9. Stambaugh, EP, Miller, JP: Hydrothermal precipitation of high quality inorganic oxides. In: Proceedings of the First International Symposium on Hydrothermal Reactions, p. 859. Gakujutsu Bunken Fukyu-Kai, Tokyo (1982)

10. Barrer, RM: Hydrothermal Chemistry of Zeolites, p. 360. Academic, Waltham (1982)

11. Sridhar, K: Nanotechnology. Current. Sci. 85, 25 (2003)

12. Chao, GY, Conlon, RP, Velthuizen, JV: Identical to UM1944-//-TeO:FeH; later described under the name poughite. Mineral Record. 21, 363 (1990)

13. Kraehenbuehl, F, Stoeckli, HF, Brunner, F, Kahr, G, Mueller-Vonmoos, M: Study of the water-bentonite system by vapour adsorption, immersion calorimetry and X-ray techniques: I. Micropore volumes and internal surface areas, following Dubinin's theory. Clay. Miner. 22, 1 (1987)

doi:10.1186/2228-5326-3-38

Cite this article as: Alemi et al.: Hydrothermal synthesis and

characterization of straw bundle-like lithium sodium disilicate (silinaite) micro-rods. International Nano Letters 2013 3:38. 